\title{
Relationship of Nursing Behavior with Treatment of Nosocomial Infections in RSUS Delitua in 2018
}

\author{
Agustina Simamora
}

Institut Kesehatan Deli Husada Delitua

\begin{abstract}
Most patients who are hospitalized get treatment and treatment from nurses according to their respective complaints. The behavior of nurses in these patients mostly can make an infection because often the action is taken in the form of therapy or not. Infection that often occurs in a hospital is called a nosocomial infection, nosocomial infection is an infection that is obtained during a patient's hospital treatment. Currently nosocomial infection is one of the causes of increased morbidity and mortality in hospitals. The aim of this study is to know in general the relationship between nurses' behavior and nosocomial infection control in Sembiring Delitua Hospital in 2018. This research is descriptive correlational, which identifies the causal relationship between the behavior of nurses and the prevention of nosocomial infections in Sembiring Delitua General Hospital in 2018. Based on the results obtained, the respondents' knowledge and attitudes in Sembiring Delitua General Hospital in 2013 will be able to overcome nosocomial infections. say well according to the results of a good questionnaire and on the respondent's actions both based on the observations of the respondent's actions can be said to be good. Thus the researchers hope that the results of this study can be a motivation in improving service quality in improving services for nosocomial infections for nurses.
\end{abstract}

Keyword: Nurse behavior, nosocomial infection.

Received 04 February 2019 | Revised 14 May 2019| Accepted 26 January 2019

*Corresponding author at: Jl. Besar No.77 Delitua Kab. Deli Serdang Sumatera Utara 


\section{Introduction}

Nasocomial infection is an infection that is obtained during a hospital treatment. Masochomial infection is currently one of the causes of increased morbidity and mortality in hospitals, so that it can become a new health problem in developing countries and in developed countries. (Darmadi, 2008).

The number of nasocomial infections recorded in several countries ranged from 3.3 to $9.2 \%$, while the incidence of nasocomial infections in several floating countries in Southeast Asia such as Malaysia was $\mathbf{1 2 . 7 \%}$ and Taiwan was $\mathbf{1 3 . 8 \%}$ (Marwoto in Habni, 2009).

In Indonesia, the incidence of nosomocial infections in hospitalized patients in surgical wards is in the range of $5.8 \%-6 \%$ and the rate of nosocomial infections in surgical wounds is $2.3 \%$ $18.3 \%$ (Hermawan, 2007). Percentage of incidence of nosocomial infections in Dr. Pringadi Medan in 2006 amounted to $32.16 \%$ which included infections caused by the use of $10 \%$ infusion needles due to blood transfusions $10.16 \%$ and $12 \%$ surgical injuries (Nasution, 2008).

At present the incidence of nosocomial infections has become one of the benchmarks for the quality of hospital services. Based on Kepmenkes no. 129 of 2008, the standard incidence of nosocomial infections in hospitals was $<1.5 \%$. Operating permits for a hospital can be revoked because of the high incidence of nosocomial infections. Even the insurance company does not want to pay the costs incurred by this nosocomial infection (Darmadi, 2008).

In Kemenkes No. 129 of 2008 stipulated a minimum standard of hospital services, including the reporting of cases of nosocomial infections to see the extent to which hospitals control these infections. Data on nosocomial infections from surveillance of nosocomial infections in each hospital can be used as a reference to prevent infection in order to improve medical services for patients (Kepmenkes, 2008).

Infection control activities in patients with infection, infection prevention, surveillance and rational treatment. And nosocomial infections according to the Minister of Health, Indonesia, and even this type of infection continues to increase from 1 percent in several European and American countries, up to more than $40 \%$ in Asia, Latin America and Africa (Hayati 2012).

The high incidence of nosocomial infections makes nurses have to implement compliant behavior in accordance with operational standards in carrying out actions in accordance with hospital provisions. This is consistent with Yusran's (2008) statement that suboptimal compliance is the main factor in the increase in nosocomial infections in health care centers. 


\section{Research Methods}

The design used in this study is descriptive correlational, which is to identify the causal relationship between the behavior of nurses and the prevention of nosocomial infections in Sembiring Delitua Hospital in 2018.

The population in this study were all nurses on duty at RSU Sembiring Delitua. Where the number of nurses in the Inpatient Institution at RSU Sembiring Delitua. total of 100 people.

The sampling technique in this study was "Accidental Sampling" where taking samples in this study was subjected to sampling because it happened to be found at the same time and place. The sample size in this study amounted to 25 people or $20 \%$ of the total nurses in Rawt Inap Installation (Arikunto, 2006).

This research was conducted in May at Sembiring Delitua Hospital in 2018. Nurse behavior data in research subjects were calculated manually and then carried out the following processes:

\section{Editing}

Done to check the completeness of the data on one union and ensure all answers are filled in according to the instructions

\section{Coding}

Data that has been changed into a number (code), namely the respondent's name is changed to the respondent's code number and the results of filling out the questionnaire are assessed according to what has been determined.

\section{Tabulating}

To simplify data analysis and data processing and conclusions data is entered into the frequency distribution. To find out whether or not there is a relationship between the two variables, namely the behavior of nurses with the prevention of nosocomial infections, statistic analysis was performed using Chi-square test using the formula:

$$
X^{2}=\frac{\sum(f o-f e)^{2}}{f e}
$$




\section{Research Result}

Based on the results of data collection regarding the relationship of nurse behavior with the prevention of Nosocomial infection in Sembiring Delitua Hospital in 2018 .. Data is obtained as follows:

\section{Demographic data}

Based on the results of the study, it is known that frequency distribution according to demographic data of respondents can be seen in the following table.

Table 1. Frequency Distribution Based on Demographic Data of Respondents in RSU Sembiring Delitua in 2018.

\begin{tabular}{|c|c|c|}
\hline Data Demografi & f & $\%$ \\
\hline Umur & & \\
\hline $22-25$ & 15 & $60 \%$ \\
\hline $26-31$ & 6 & $24 \%$ \\
\hline $32-40$ & 4 & $16 \%$ \\
\hline Total & 20 & $100 \%$ \\
\hline Jenis Kelamin & $\mathrm{F}$ & $\%$ \\
\hline Laki-laki & 14 & $56 \%$ \\
\hline Perempuan & 11 & $44 \%$ \\
\hline Total & 25 & $100 \%$ \\
\hline Tingkat Pendidikan & 2 & $8 \%$ \\
\hline SPK & 21 & $84 \%$ \\
\hline AKPER & 2 & $8 \%$ \\
\hline S1 Keperawatan & & \\
\hline Total & 25 & $100 \%$ \\
\hline Lama Kerja & & \\
\hline$<1$ Tahun & 9 & $36 \%$ \\
\hline$>1$ Tahun & 13 & $52 \%$ \\
\hline$>5$ Tahun & 3 & $12 \%$ \\
\hline Total & 25 & $100 \%$ \\
\hline $\begin{array}{c}\text { Pelatihan } \\
\text { penanggulangan }\end{array}$ & & \\
\hline Infeksi & 2 & $8 \%$ \\
\hline Pernah & 23 & $92 \%$ \\
\hline Tidak $\mathrm{p}$ & & \\
\hline
\end{tabular}




\begin{tabular}{|l|l|l|}
\hline Total & 25 & $100 \%$ \\
\hline
\end{tabular}

Based on the table above, it was found that the majority of respondents aged 22-25 years as many as 15 nurses and minority respondents aged 32-40 years as many as 4 nurses. For the respondent's gender gender the majority of men were 14 nurses and minorities were female 11 nurses.

For the education level, the majority of respondents educated were 21 respondents and a minority were educated Akper and SPK with a total of 2 respondents. For the duration of work the majority of respondents worked> 1 year as many as 13 respondents and a minimum duration of employment> 5 years. respondents never attended training as many as 23 respondents and a minority of respondents who did not take part in the training were 2 respondents.

The demographic characteristics of the respondents consisted of gender, age, marital status, recent education, occupation, duration of chronic kidney failure, frequency of hemodialysis every week, and involvement of family or closest people during hemodialysis. The results of this study were that respondents with male sex were more than women, that is, 62 people (58.5\%), the age range of the respondents was mostly between the ages of 41-60 years, that is, 73 people (68.9\% ), the majority of respondents have married as many as 99 people (93.4\%), the last education of the respondents was mostly at the high school level, 47 people (44.3\%), more than half of the respondents did not work, 66 people $(62.3 \%)$, the majority of respondents have suffered chronic kidney failure $\geq 1$ year, that is, 95 people $(50 \%)$, all respondents did $2 \mathrm{x}$ hemodialysis per week, that is, 105 people (99.1\%), and 62 respondents (58.5\% ) accompanied by family or closest people while undergoing hemodialysis.

\section{Nurse Behavior}

Based on the results of the study note Frequency Distribution according to the behavior of respondents can be seen in the following table.

Table 2. Frequency Distribution according to the respondent's behavior.

\begin{tabular}{|c|c|c|}
\hline Behavior & f & $\%$ \\
\hline 1. Knowlage & & \\
Good & 14 & $56 \%$ \\
Bad & 11 & $44 \%$ \\
\hline Total & 23 & $100 \%$ \\
\hline 2. Attitut & & \\
Positif & 16 & $64 \%$ \\
Negatif & 9 & $36 \%$ \\
\hline
\end{tabular}




\begin{tabular}{|c|c|c|}
\hline Total & 25 & $100 \%$ \\
\hline 3. Acction & & \\
Done & 18 & $75 \%$ \\
Not Done & 7 & $28 \%$ \\
\hline Total & 25 & 100 \\
\hline
\end{tabular}

\section{Management of nosocomial infections.}

Based on the results of the study, it is known that frequency distribution according to the prevention of nosocomial infections can be seen in the following table.

A. Statistical analysis based on respondents' knowledge.

To find out the statistical analysis of respondents' knowledge, several steps were carried out, namely:

a. Knowing the percentage of each questionnaire question regarding nurses' knowledge with nosocomial countermeasures.

Table 3. Frequency Distribution based on the prevention of Nosocomial infections in Sembiring Delitua Hospital in 2018.

\begin{tabular}{|l|l|l|}
\hline Demografic Date & $\mathbf{f}$ & $\mathbf{\%}$ \\
\hline Management of nosocomial & & \\
infections & & \\
Action is appropiate & 13 & 52 \\
Action is not appropiate & 12 & 48 \\
\hline Total & $\mathbf{2 5}$ & $\mathbf{1 0 0 \%}$ \\
\hline
\end{tabular}

B. Results of Statistical

Analysis To find out the relationship between nurse behavior (knowledge, attitudes and actions) with nasocomial countermeasures, the chi-square test was carried out as follows:

\section{Discussion of Nurse Behavior}

Based on the frequency distribution of the research results from 25 respondents to the knowledge of nurses with nosocomial infection control, well-informed nurses as many as 14 respondents (56\%), as well as the attitude of respondents to the assessment and assessment of nosocomial infection prevention as positive as 16 respondents $(64 \%)$ 
Based on the actions that have been carried out by nurses related to prevention of nosocomial infections with the majority of nurses as many as 18 respondents $(72 \%)$.

\section{Management of Nosocomial Infection}

The prevention of nosocomial infections by nurses based on observations made by researchers as many as 13 respondents (52\%).

\section{Relationship between nurse behavior and prevention of nosocomial infections}

1. Knowledge of nurses with nosocomial infection control results obtained that there is a significant relationship between knowledge and prevention of nosocomial infections, can be seen clearly in the table below:

\section{Knowledge Observation1 Crosstabulation}

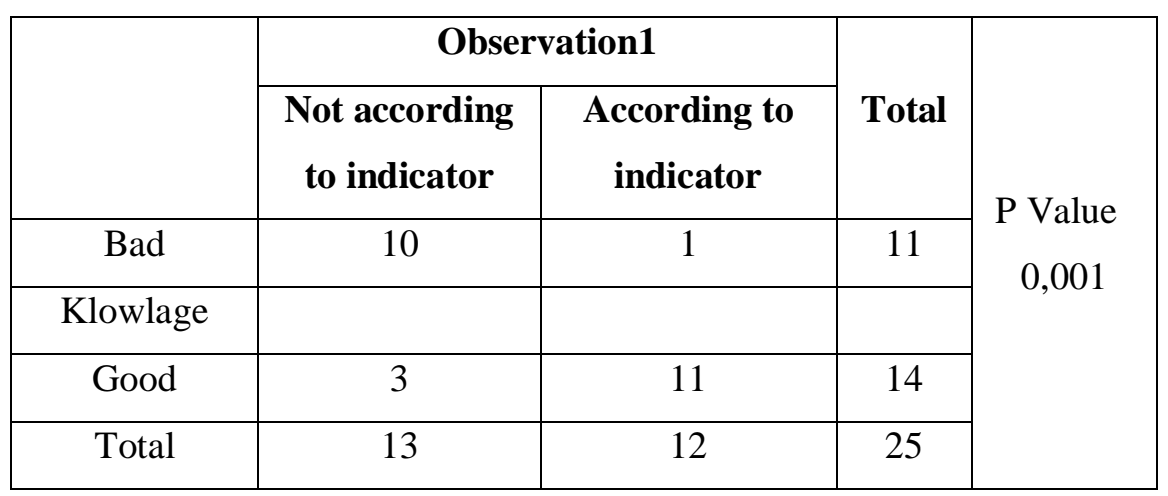

2. The attitude of nurses with the prevention of Nosocomial infections shows that there is a significant relationship between attitudes and prevention of nosocomial infections can be seen clearly from the table below:

Sikap *Observasi2 Crosstabulation

\begin{tabular}{|c|c|c|c|c|}
\hline \multirow{2}{*}{} & \multicolumn{2}{|c|}{ Observation2 } & Total & $\begin{array}{c}\text { P Value } \\
0,000\end{array}$ \\
\cline { 2 - 4 } & Not according & $\begin{array}{c}\text { correspon } \\
\text { ding }\end{array}$ & \multirow{2}{*}{} \\
\hline $\begin{array}{c}\text { Positive } \\
\text { attitut }\end{array}$ & 8 & 1 & 9 & \\
\hline Negatif & 1 & 15 & 16 & \\
attitut & & 16 & 25 & \\
\hline Total & 9 & 16 & \\
\hline
\end{tabular}


3. In the actions of nurses with the prevention of nosocomial infections, the results show that there is a significant relationship between actions with the prevention of nosocomial infections can be seen clearly from the table below:

\section{Count}

\begin{tabular}{|c|c|c|c|c|}
\hline & \multicolumn{2}{|c|}{ Observasi3 } & Total & $\begin{array}{c}\text { P Value } \\
0,000\end{array}$ \\
\cline { 2 - 4 } & $\begin{array}{c}\text { Not } \\
\text { According }\end{array}$ & $\begin{array}{c}\text { Correspondi } \\
\text { ng }\end{array}$ & \\
\hline $\begin{array}{c}\text { Action not } \\
\text { taken }\end{array}$ & 7 & 0 & 7 & \\
\hline Do & 0 & 18 & 18 & \\
\hline Total & 7 & 18 & 25 & \\
\hline
\end{tabular}

\section{Conclusion}

Based on the results of the research obtained, the knowledge and attitudes of respondents, Sembiring Delitua Hospital in 2018. Nosocomial infection control will be said to be good in accordance with the results of good questionnaires and on the respondent's actions based on observations of respondents' actions can be said to be good.

From the results of the analysis by carrying out the chi square test the results obtained were that there was a significant relationship between knowledge with the prevention of nosocomial infections, with a value of $\mathrm{p}$ value 0.001 . Which means ha is accepted and has a significant relationship. And the attitude of nurses with the prevention of nosocomial infections was obtained that there was a significant relationship between attitudes and prevention of nosocomial infections with a $p$ value of 0,000 . Which means that the more positive the nurse's attitude, the more appropriate the actions taken.

\section{Suggestion}

Based on conclusions, the suggestions and inputs that must be considered are as follows:

1. For nursing research

This research was only conducted in one hospital so that the results of subsequent studies are expected to do better. 
2. For educational institutions

Expected to health services and students to understand what nosocomial infections are.

3. For nurses

It is hoped that the research that has been conducted has become a motivation in improving service quality in improving services for nosocomial infections for nurses.

\section{REFERENCES}

[1] Brosche, Theresa Ann Middleton. 2013. Buku Saku EKG. Buku Kedokteran. Jakarta:EGC

[2] Erwin Kusuma Tubagus. 2013. Bebas Hipertensi dengan Self - Hypnosis. Selatan:PT Mizan Publika. Jakarta Selatan

[3] Gunawan Lany. 2001.Hipertensi. Yogyakarta:Kanisius

[4] Hadyanto Lim Prof. 2011. Farmakologi Kardiovaskuler: Mekanisme dan Aplikasi Klinis. Jakarta:Sofmedia

[5] Hartono LA. 2007. Stres \& Stroke. Yogyakarta:Kanisius

[6] Hayati, Suci Dian. Mencegah Infeksi Nosokomial. Jurnal Nasional, Edisi Minggu 15 Januari 2012, hal 23

[7] Kowalski, E Robert. 2013. Terapi Hipertensi. Surabaya:Qanita

[8] Kozier Barbara, dkk. 2010. Buku Ajar Fundamental Keperawatan Konsep,Proses, dan praktik (Fundamentals Of Nursing: Concepts, Process and Practice). Buku Kedokteraan . Jakarta:EGC

[9] Muttaqin Arif. 2009. Asuhan Keperawatan Pada Klien dengan Gangguan Sistem Kardiovaskular. Jakarta:Salemba Medika.

[10] Najimah, 2011. Management dan Analisa Data Kesehatan ( Kombinasi Teori dan Aplikasi SPSS). Yogyakarta: Nuha Medika. 
[11] Nurssalam. 2003. Konsep dan Penerapan Metodologi Penelitian Ilmu Keperawatan. Jakarta:Salemba Medika.

[12] Petroudi, D. 2009. Nosocomial Infection and staff hygiene, journal of infection in developing countries, Hal. 3(2): 152-156.

[13] Sani Rachman. 2012. Yoga Untuk Kesehatan. Semarang: Effhar Offset.

[14] Supardi Subyo. 2013. Metodologi Riset Keperawatan. Jakarta: Trans Info Media. 